\title{
Georges Bataille and the Transgression of Taboos by Stephan Dedalus
}

\author{
Shataw Naseri (Corresponding author) \\ Faculty of Human Sciences, Shahid Beheshti University, Iran \\ Kian Soheil \\ Faculty of Human Sciences, Shahid Beheshti University, Iran
}

Received: 26-05-2014

doi:10.7575/aiac.ijclts.v.2n.3p.50
Accepted: 22-06- 2014

Published: 01-07- 2014

\begin{abstract}
James Joyce's $A$ Portrait of the Artist as a Young Man is not a pornographic novel like Georges Bataille' Story of the Eye; however, the present study attempts to trace Bataille's heterological notions in A Portrait. This paper attempts to see whether or not Stephan Dedalus as the main character of Joyce's literary work, has the potential to carry Batatille's heterogeneous elements which shatter any religious, linguistic, economic and political system. In order to reach this goal, the paper first attempts to establish the powerful dominance of the Catholic discourse, one of the strictest religious systems in the world, over Ireland which is the main setting of $A$ Portrait. In the next part it will trace the authoritarian shadow of Catholicism and its impression upon Stephen Dedalus. Here, the principal aim is to indicate the significance of Stephen's transgressive acts in the novel and to see whether these transgressions have Bataillean nature as they shatter a very strict religious structure. Afterward, Stephen's transgressions as well as the implicit reaction of the religious system toward these transgressions will be investigated regarding Georges Bataille's heterogeneous notions.
\end{abstract}

Keywords: Taboo, Base Materialism, Accursed Share, Eroticism

\section{Georges Bataille and the Origin of his "Foreign" Philosophy}

The sorrowful and lunatic screams of Georges Bataille's father had a deep influence upon his work and all his writings are interwoven with the dark nightmares he had experienced due to this situation in his childhood. He writes himself that when he was born, his father was suffering from general paralysis, and that he was already blind when he conceived his baby son. A short time after Bataille's birth, the horrible disease of syphilis confined his father to an armchair. The son confesses that the weirdest and the very most sorrowful point about his father was that his pupils frequently pointed up into space, shifting under the lids, when he was toileting in the room with the help of Georges. Bataille in Story of the Eye asserts that "he [his father] had huge, ever-gaping eyes that flanked an eagle nose, and those huge eyes went almost entirely blank ... with a completely stupefying expression of abandon and aberration in a world that he alone could see and that aroused his vaguely sardonic and absent laugh" (Bataille 93). This sardonic laughter as well as the shattering screams of his poor father while experiencing some extreme pains were for Georges the violators of the highest values of morality, dignified self, and defined borders.

Throughout his whole oeuvre, Bataille was seeking for these "sovereign" (Noys 74) and destructive experiences, which imply experiencing boundless freedom, freedom from language, discipline, morality, utility, culture, identity and so forth. The sardonic screams of her father created some "sovereign" moments, in Bataille's sense, as those transgressive instants were governed by no systematic rules and they were sovereign themselves.

Bataille in his works as well as throughout his whole life, did not seek new knowledge, rather he sought "Impossible" freedom (freedom whose complete achievement is Impossible, but toward which one must strive all his life). For Georges, "Impossible" is some endless abyss which no one can reach. He wrote with endless compassion for human frailty and devotion to human freedom. As a psychologist, a philosopher of language, a novelist, a poet, and a mystic, Bataille explored the limits of knowledge, human communication, linguistic discourse, and narrative. As an atheist in a deeply Catholic country, Bataille threw himself on the throat of his God and sacrificed the limiting and binding values of his time through an active destruction. In fulfilling his determination to cross the defining borders he wrote many of his works in pseudonym publications, as Stuart Kendall asserts in his book Georges Bataille. He wrote to disrupt all the assumptions which might make his recognition possible and his aim was to make heterogeneous and different elements be communicated in his oeuvre.

\section{The Irish Catholic Church}

James Joyce's novel A Portrait of the Artist as a Young Man is dominated by the strict utilitarian system of Irish Catholic Church, which is the most significant cult of Christianity in Ireland. The dominance of Catholicism over the Irish people is obvious at the very beginning of the novel with the presence of Dante as an efficient representative of the Catholic Church; she as a loyal proponent of the Church establishes one of the fundamental motifs of the Irish 
Catholicism, namely the motif of punishment, in the book. At the beginning of chapter one, she asks the child Stephen to apologize and that if not the eagle will pull out his eyes:

\author{
Pull out his eyes, \\ Apologize, \\ Apologize, \\ Pull out his eyes.
}

These lines are very important since they indicate how Stephen from the first becomes familiar with the state of being punished in the case of deviation. Stephen is terrorized by these nursery rhymes; in his world the nice images of the moocows of the few first pages of the novel (which are the symbols of Ireland) are overwhelmed by the fierce eagles of the religious collective ideology. Stephen must apologize from this very point in order to be.

Furthermore, the dark and horrifying atmosphere of the religious Catholic order of the school is not only imposed through the orders and the punishment of the Jesuits, but also through the very dim and dark atmosphere of the buildings. The terrifying grandeur of the Irish Catholic Church has been reflected in the low dark narrow corridors of the school; these dark and gloom corridors are repeated through Stephen's mind several times in the novel, particularly in the first chapter. When he passes through the silent and dark corridors to get to the rector's room he observes on the walls some portraits of the great saints of Christianity which convey a sense of awe and fear to the observer. He observes the portraits of the saints and the great men of Catholic cult,

\begin{abstract}
Saint Ignatius Loyola holding an open book and pointing to the words Ad Majorem Dei Gloriam in it; saint Francis Xavier pointing to his chest; Lorenzo Ricci with his berretta on his head like one of the perfects of the lines, the three patrons of holy youth- saint Stanislaus Kostka, saint Aloysius Gonzago, and Blessed John Berchmans, all with young faces because they died when they were young, and Father Peter Kenny sitting in a chair wrapped in a big cloak. (56)
\end{abstract}

These religious figures dominate the space of the building led to the room of the rector. In fact, the dominance of the Catholic figures is perceived throughout the whole novel. The Irish Catholic Church is present every moment and everywhere in Irish people's lives.

However, the most important presence of the Catholicism is after Stephen's committing the transgressive orgies in the second chapter as well as at the beginning of the third chapter. He is pondering on the nature of his erotic acts when the word retreat emerges in the novel. It is here that the dominant presence of religion is best embodied; it is here that the lecture of Father Dolan begins which best reveals the horrible aspects of the Catholic religion. Here, for the first time in A Portrait, the items of death, judgment, hell, and heaven are raised. Father Dolan asserts that "we have been sent in to this world for one thing and for one thing alone: to do God's holy will and to save our immortal souls. All else is worthless. One thing alone is needful, the salvation of one's soul" (110).

All these elements suggest the presence of Catholicism and its Church in Irish world and its strict influence upon all the thoughts and actions.

\title{
3. Bataille's Notions and Joyce's $A$ Portrait of the Artist as a Young Man
}

Stephen is very suitable for Georges Bataille's view of this profane world in which all the beings are "discontinuous beings." Bataille believes that in the ordered systematic societies (such as Catholic Ireland) although the beings have different kinds of relationship- business, familial, and so forth- with each other, there is no true continuity between them and because of the boundaries, limits, and the restraining lines which create distance between them, they are discontinuous and distinct from each other. Bataille believes that his "sovereign" moments which transgress the ruling systems, although for brief moments, and bridge the gap between the human beings, can stream the continuity between them and liberate them from discontinuity. For Stephen, this state of being discontinuous from his environment and his other fellow beings is obvious, and later on in the novel this discontinuity becomes even more intensive.

Stephen is utterly obedient to the Catholic system of his school. Even when he is pandied by the perfect of studies, he remains submissive to the system and his protest to the rector following his punishment is not violent and transgressive. However, Stephan gradually goes on aimless wanderings throughout the alleys of Dublin in search of Mercedes and it is here that he is beginning to flow within the strict religious system. He is willing to be different from his environment which has been surrounded by abstract and "intangible phantoms" (84) of honor, manhood, and comradeship. There are about him the constant voices of his parents and of his masters who urge him to be a gentleman and a good catholic above all things. But Stephen ignores their "hollow-sounding" (84) voices and he is only happy when he is secluded from their phantasmal ideals.

Here, Stephen is indeed getting away from what Georges Bataille terms the "project" of the world of order. Bataille in his book The Accursed Share claims that the profane project of this "profane world" (Joyce 84) is serving an end, a useful finality. This profane project is the anticipation of the results of the performed labor, or, in general, the laborious 
activity and setting aside the validation of chance, contingency, or any momentary and transgressive impulse which are desirable for Bataille's notions and which are not based on anticipated results.

Georges Bataille believes that Christianity and its moral order are interdependent with utilitarianism and the order of things. He claims that human existence is regulated in the world of work and utility, and this profane world is interwoven with Christianity and thus its God-Head as the center, Who validates labor and its concomitant promise of future recompense. Bataille calls this world of order of things the "world of project" which he defines as the world of means and ends with the economy of calculation. For him, this profane world is a world structured according to some basic economic values of the Christian morality. This religious cult commands laborious attempts and inhibits laziness, sloth, and the state of being inactive. It also stresses the ends and the usefulness of these labors and attempts. As Bataille claims even the notion of salvation, which for Christianity takes place in the world of beyond and not in this earthly world, is interwoven with the idea of usefulness and its concomitant notion of the linearity of time and space.

Stephen's nerves are crying for adventure but what kind of adventure and for what kind of purpose is not obvious even for himself. He with these purposeless wanderings and stirring desires lives in Dublin, which is a Catholic bourgeois society with the privilege of production and utility and with a commodity culture. The fact of this usefulness-loving society is very clear first in Stephen's discussion with Lynch over women and their own society's view toward them in the last chapter. Throughout the discussion, Stephen asserts that every item for their people has a kind of usefulness and that nothing exists for them as an end in itself and without having a previous view of its utility. Everything is a tool in this community with an anticipated result and this is undeniably what Georges Bataille claims about a Christian bourgeois society. He claims that for such a society everything is a tool with a specific result; nothing is valuable if it does not have a utilitarian and non-esthetic end. Stephen as a Bataillean character brings for Lynch the example of women and female beauty. He says that even female beauty isn't valuable for men if it does not have any advantage out of itself; female beauty is not beautiful for itself but for a projected and predictable benefit. Stephen believes that "[e]very physical quality admired by men in women is in direct connexion with the manifold functions of women for the propagation of the species" (Joyce, 208); he tells Lynch that "you admired the great flank of Venus because you felt that she would bear you burly offspring and admired her great breasts because you felt that she would give good milk to her children and yours" (208).

The most obvious clue of Catholicism's cult of utilitarianism is its notion of salvation. One of the most recurring motifs of the book, particularly in the religious preachment of Father Arnall in the third chapter of the novel, is the term "salvation". This item is interwoven with the notion of utility since this fictive promise, according to Bataille, urges the subjects of Christianity to do moral acts and to be moral slaves hoping that their laborious obedience will be rewarded in the next world. There is no holy business in Christianity without the promise of salvation and thus usefulness in the future. Bataille preserves that in a Christian bourgeois society the moral servers like its laborers are reduced to thinghood and to the results of their passive and laborious moral servitude.

The principle of production and the accumulation of wealth in a bourgeois society is the case also in Christianity, which values the accumulation of grace and virtue rewarded by salvation in the world beyond. This point is observed evidently in the tormenting religious lecture of Father Arnall. It is in this preachment that the term "salvation" is present dominantly. Arnall declares that "we have been sent into this world for one thing and for one thing alone: to do God's holy will and to save our immortal souls. All else is worthless. One thing alone is needful, the salvation of one's soul" (110). Through the promise of salvation, Bataille asserts, Christianity with its God-head Who is addressed as "Good Shepherd" (114) urges the people to moral servitude and thus to obey the precepts of the holy Church and to attend the religious duties as one observes in the above comments from the preacher.

As mentioned, Stephen has restless and powerful tides within his soul which cause him to wander throughout the alleys of Dublin aimlessly and by the baffles of desire. He in this phase of his psyche is completely on the brink of transgressing the limiting erotic taboo and therefore transgressing the grandeur and majesty of the Irish Catholic Church and its God-Head, Who prevents the Christian ones from committing any type of sin in deed as well as in thought. Stephen is away from the defining laws and taboos of the Hegelian and Christian vertical axes. Vertical axes, in Bataille's sense, are all those systems which govern and rule human beings. They are vertical and neglect the horizontal axes of transgressive laughter, poem, ecstasy, eroticism, contingency, drunkenness and any other sovereign actions which shatter the vertical and utilitarian rules (although for brief moments) and making the beings to approach "Impossible".

Here, Stephan is moving on the Bataillean horizontal axis and he has started to ooze throughout the whole Hegelian and Catholic order. He cannot be dammed up from his mobility; he is no longer a solid and stable submissive person within this stabilizing and homogenizing frame. His unrest and his "wasting fires of lust" (100) spring up over and over within his soul; and the "verses passed from his lips and the inarticulate cries and the unspoken brutal words rushed force from his brain to force a passage" (100).

According to Joseph Valente in his book Joyce and Sexuality, there is interdependence between impulses to submission and transgression; thus the instant of Stephen's submission to the prostitute, which for Bataille in his book The Theory of Religion is the representative of luxurious consumption, is the instant of his transgression against the Catholic system. Stephen's committing eroticism is different from animals' sexuality in that, according to Georges Bataille in his book The Accursed Share, eroticism is not merely sexuality, but it is committed through conscious transgressing the taboo of sexuality. Eroticism is breaking the prohibiting moral limits; it is violence against the defining borders of society, because any transgression is accompanied by the violent breaking of the taboos. His transgression is, indeed, an 
act of "aggressive pleasure," "surplus juissance." Stephen experiences a "transgressive pleasure in violating the sexual norm" (226). He experiences surplus and extreme and surplus juissance (a Bataillean concept) and ecstasy in crossing the taboos and which itself is a horizontal element.

According to Georges Bataille, committing a banned erotic act and any horizontal accursed act is committing sacrifice. He believes that when one performs an erotic act, he or she sacrifices violently the fixed boundaries of the self and the society, and thus the head or the heads of this self and society; accordingly, in a Christian discourse crossing any erotic taboo is sacrificing God-Head of the system, whose prohibitive command of eroticism out of the marriage system is transgressed. Bataille believes that eroticism is one of the principal acts in which through crossing and breaking all the defining borders the dignity of the body is shattered; the participants of the erotic orgy are no longer "discontinuous beings" because the limiting and the surrounding boundaries between these two beings collapse at the moment of eroticism. There is no limit, no boundary at that aggressive and consumptive moment and thus they experience a momentary "continuity".

Bataille believes that the instant of erotic act is the instant of "NOTHINGNESS" because at that moment any taboo and limit is nothing and every frame and limit falls. God is absent in that moment; no head, no center attends that consumptive moment. In the erotic act the partners are, indeed, Bataille's Acephalic figures who have slaughtered the present heads of the self and the social body violently; just the lower parts of the body rule that luxurious moment and the heads have been beheaded. All these facts are the case for Stephen Dedalus; his "consuming desire" (Leonard 91) sacrifices the whole boundaries of his own self and also God-Head of the Irish Catholic Church. The absence of the Catholic Church and its God-Center is obvious at that moment of his transgressing the sexual taboo.

In the following nights he again desires to experience erotic instants; he repeats his orgies recurrently in a cyclic pattern. $\mathrm{He}$ is waiting for a cunning eye and for a sudden movement in the dark and obscene corners. He becomes in these orgies a Bataillean insatiable and Acéphalic beast who again and again roams in the infamous regions of the city thirsty for taking the consumptive chance.

Stephen in his obscene wanderings does not have any, as Bataille terms, "profane project" with the aim of a utilitarian result, no prediction, no goal of production or accumulation of wealth rules those wanderings. In those dirty alleys of Dublin he just waits for an instant; only chance governs those impulsive moments. Here chance and instant are the only elements which are important for Stephen Dedalus. Chance in an instant is one of the other disruptive elements which situate on the Bataille's horizontal axis and which effaces all the ruling systems momentarily.

Stephen is a real transgressor; the sins which up to now he dared not commit even in his thought are done by him easily and without the pain of conscience. He is a Bataillean Acéphale figure with a sword in his right hand, who sacrifices violently his own head as well as the God-Head of the body of Christianity. It is after succumbing to these deadly sins that he dares questioning some up-to-now take-for-granted routines of Catholicism. He questions the true nature of baptism as well as the use and the origin of bread and wine in Catholicism. Up to this point in the novel there is no trace of such fundamental questions; Stephen was a loyal and obedient subject to all the norms of Catholicism as well as "the rigid lines of the doctrines of the church" (Joyce 106).

Stephen transgresses the taboos deliberately and with the aim of transgressing them; however, after hearing the threatening lecture of Father Arnall in the middle of chapter three of $A$ Portrait, he regrets intensively having crossed the defined lines of the Church. This is what Georges Bataille terms as "anguish." He preserves that crossing the defined limits of the closed system within which one lives leads to anguish and anxiety and this is because these taboos are rooted so fixedly within the self and the psyche of the transgressor that their energetic and consumptive transgression leads him or her to experience a kind of anguish and suffering. These strong-rooted taboos exist even when they are transgressed. If they do not exist, there will be no transgression; because transgression is, in fact, breaching these taboos, however, taboos are there again. The erotic taboo, which Stephen Dedalus crosses within the extremely strict frame of Catholicism is there again and its breaching causes the pain of conscience and Bataillean anxiety within him.

Bataille in his famous essay "Obelisk" states that "Obelisk" is a statute upward toward the sky and which was situated at Place de la concorde in Paris in 1838 and that it marks the place of guillotine, the tool of violent death. Bataille believes that the existence of "Obelisk" suppresses death and its extreme violence beneath; however this violence with its disruptive energies cannot be suppressed absolutely. It flows underneath this absolutism. For Stephen in this point of the novel it is so and beneath his state of absolute spirituality which even leads to pantheism, the fluid of impulsive energies and the Bataillean "void" (the dissonant cracks and the gaps which exist in the structural systems) with their violent potentiality is present. It is here that doubt grows within his spiritual dryness and the voices of flesh murmur when he is praying to God and he is proud of the fact that he has the power to shatter all that he has done in an instant. He is now being attacked by the flood of violent temptations and in his confessions to the confessor he comes to the point that he would never be completely freed of the sin that he has committed and that "an unresting doubt flew hither and thither before his mind" (Joyce 157).

Later again, Stephen starts oozing within the strict lines of the Irish Church again but this time more destructively. Again he is passionate for chaos and instability; the disorder and the misrule of his father's house attracts his interest now. Stephen is again inclining towards the horizontal axis with all its admiration of unlawfulness and "the domain of accursed share." He is, indeed, fluctuating between the vertical and the horizontal axes. Georges Bataille in his essay "The Solar Anus" writes that it is human beings among the animals who are continuously fluctuating between these two axes and that as soon as they step on the horizontal axis, the state of anguish pulls them back again onto the vertical axis 
and vice versa. Bataille believes that this fact is like the waves of the sea upward and move downward over and over without reaching any solid situation.

After having his impulsive epiphany moment with seeing the girl at the beach the project of his life is broken again and he inclines toward art. After understanding his true career experiences a kind of ecstasy which dissolves the linear time and narrative. His true career is being a free artist not being the priest of the Irish Catholic Church. Stephen experiences ecstasy, and ecstasy is a Bataillean experience which belongs to the domain of the accursed share. It is, in fact, here at this ecstatic moment that Stephen's throat expresses a loud cry which itself is a Bataillean horizontal action. He feels this cry as a cry full of life; it is not a call from an inhuman voice calling him to the cold altar. It is a cry which transfigures any order. Stephen, an Acéphale figure, beheads all the heads of the taboos of linear time, place, narrative and any other system. This instant is for him an instant of wild flight. He is a destructing wanderer now just like his last time of being involved in Bataillean "base materialism," when he was entrapped within his erotic orgies. He is a headless destructor roaming within the system of the narrative, determined to remove the taboos. However, in the period when he again converted to Catholicism and was a very loyal obedient to all the laws of God and His Catholic Church, the reader of the novel observes no purposeless wandering; during this submissive period everything was planned and projected and he does every divine act in order to be rewarded in the world beyond, a Catholic bourgeois behavior.

At the beach, Stephen concentrates upon the details of the body of this girl, who is, for him, the representative of the mortal beauty. The nature of this image is sexual because Stephen's depiction of her is erotic; therefore, one concludes that at the basis of his artistic inspiration there exists erotic material. It is here that he again experiences the shattering ecstasy. He cries devastatingly with the outburst of a profane joy; he turns away from the girl and wanders savagely towards the seaside, singing brutally to the sea:

On and on and on and on he strode, far out over the sands, singing wildly to the sea, crying to greet the advent of the life that had cried to him. Her image had passed into his soul forever and no word had broken the holy silence of his ecstasy. Her eyes had called him and his soul had leaped at the call. To live, to err, to fall, to triumph, to recreate life out of life! A wild angel had appeared to him, the angel of mortal youth and beauty, an envoy from the fair courts of life, to throw open before him in an instant of ecstasy the gate of all the ways of error and glory. On and on and on and on. (172)

This is Stephen's second conversion to the mortal beauty. This time he aims to abandon all the traps of the framing systems and to step in the domain of art which is itself an accursed domain.

To be an artist moving on the Bataille's axis of horizontality, he must forget the heavenly elements and must attend the earthly materiality. He needs to "destroy the heavens, dispel the ghosts [of history], stop looking upward, and start creating the very earth in which they were solidly anchored" (Buttigieg 192). Stephen's new world of mortal beauty is unfolding to him and his new liberated soul is to embrace the new world. After experiencing this epiphany scene at the seaside Stephen is willing totally toward the artistic domain; and one morning near the dawn, after experiencing another ecstatic moment, he is inspired at a very instantaneous instant which leads to his spontaneous act of the creation of the villanelle, which has in fact a sexual nature. In this villanelle the naked body of the temptress "yielded to him like a shining cloud, enfolded him like water with a liquid life" (Joyce 223). This poem conveys the sexual nature of Stephen's art rather than any divine or spiritual nature.

Now, Stephen is a complete dissonant element and, as Bataille calls, a "foreign body," within the system. In the following pages of the novel he is thoroughly preoccupied with sin against God, so that when he utters the words of Lucifer "non servium," he attests to the power of God and like Lucifer rejects serving God. Through this rebellious utterance he rejects the phantasm of God and phantasm of the past. Stephen must start creating his world, having cleared his mind (not permanently, of course) at last of the "gnawing phantasmatics that has until now barred him from genuine creativity" (Buttigieg 202). According to Derek Attridge, this revolt is the particular revolt of an artistic heretic against the strict official doctrine, which has seized the mind of the mass.

Stephen's more intensive rebellion against this doctrine is his decision to exile himself from Ireland. As mythological Daedalus built wings to escape the labyrinth in which he has been imprisoned, he tries to fly from the labyrinth of Ireland. He imposes an exile against himself and this exile is his most significant step to awaken himself from the nightmarish history of the Church. His exile, in fact, is a rebellious flight from history, from the monumental history. His soul wills freedom by escaping history and all its heads; he wishes to bury history with its dead centers: "Soul free and fancy free. Let the dead bury the dead. Ay. And let the dead marry the dead" (Joyce 248). Stephen abandons Ireland and wishes to abandon history.

Stephen Dedalus is a Bataillean figure; he is a heterogeneous and indigestible element within the body of Christianity. He transgresses the most prohibited taboo of Christianity, erotic taboo, over and over; afterward he commits all the other Deadly Sins. When he experiences the Bataillean "anguish" because of his transgressing the taboos, he devotes his whole being to Christianity and he is to be a priest. However, he rejects this vocation, and simultaneously rejects God and expresses Lucifer's famous "non servium" expressed at the moment of his transgression against God. Stephen wants to commit sin over and over; he is a foreign figure like Georges Bataille himself, a "waste product" which must be himself because he cannot be digested; he is a dissonant element within the harmonious body of Catholicism; he is 
disturbing bee which buzzes in the ears of the system and annoys the present assonant and organic unity through his commitment of the Bataillean obscene and heterological acts. He does not follow any reasonable project; he is led by his impulsive and explosive savage desires which disrupt any organism.

\section{References}

Attridge, D. (2004). Joyce's Effects on Language, Theory and History. Cambridge: Cambridge University Press.

Bataille, G. (1991). The Accursed Share. Trans. Robert Hurley. 3 vols. New York: Zone Books.

--- (1962) Death and Sensuality: A Study of Eroticism and the Taboo. New York: Walker and Company.

---Theory of Religion. (1989). Trans. Robert Hurley. New York: Zone Books.

Brown, R. (1985) James Joyce and Sexuality. New York: Cambridge University Press Us.

Buttigieg, J. A. (1981). "The Struggle against Meta (Phantasma)-Physics: Nietzsche, Joyce and the Excess of History." Boundary 2, Vol. 9/10, No. 3. Duke University Press. 187-207. <http://www.jstor.org/stable/303120>

Joyce, J. (2011). A Portrait of the Artist as Young Man. London: Urban Romantics.

Kendall, S. (2007). Georges Bataille. London: Reaktion Books Ltd.

Leonard, G. (1995). "The City, Modernism, and Aesthetic Theory in A Portrait of the Artist as a Young Man." NOVEL: A Forum on Fiction, Vol. 29, No. 1. Carolina: Duke University Press. 79-99.<http://www.jstor.org/stable/1345541>

Noys, B. (2000). Georges Bataille: A Critical Bataille Introduction. London: Pluto Press. 